\title{
Plasma Exchange in Critically III Children: A Single-center Experience
}

\author{
Kritik Hastalığı Olan Çocuklarda Plazma Değişimi: Tek Merkez Deneyimi
}

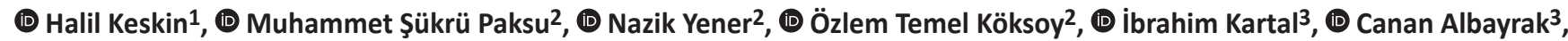 \\ (1) Davut Albayrak ${ }^{3}$
}

${ }^{1}$ Atatürk University Faculty of Medicine, Division of Pediatric Intensive Care Unit, Erzurum, Turkey

2Ondokuz Mayıs University Faculty of Medicine, Division of Pediatric Intensive Care, Samsun, Turkey

${ }^{3}$ Ondokuz Mayıs University Faculty of Medicine, Division of Pediatric Hematology, Samsun, Turkey

\section{Abstract}

Introduction: The aim of this study was to identify demographic and clinical characteristics of patients who were subjected to plasma exchange (PE) at our unit, and to investigate the effect of these factors on treatment outcome and patient prognosis.

Methods: Demographic, clinical and laboratory data of patients who were subjected to PE between January 2012 and August 2015 were obtained from the hospital information system, medical records and the records of apheresis unit.

Results: Plasma exchange was performed in 40 patients for 168 times throughout the study. The median age of the patients was 9.4 (range: $1.5-17.3$ ) years, with a male/female ratio of 1.35 . Of the patients, $47.5 \%$ had an underlying disease. The most common comorbidity was malignancy. The most common indication for PE was sepsis-related multiple organ failure $(n=19,47.5 \%)$. The mortality rate was higher in patients with an underlying chronic disease, compared to those without ( $25 \%$ and $7.5 \%$, respectively). No life-threatening complication associated with the apheresis procedure was observed. Conclusion: Our results suggest that PE can be safely performed in children. It seems that indication for PE and the presence of underlying diseases are affecting the mortality rate.

Keywords: Plasma exchange, critical patient, child

\section{Öz}

Giriş: Bu çalışmanın amacı ünitemizde plazma değişimi (PD) uygulanan hastaların demografik ve klinik özelliklerinin belirlenmesi, tedavi sonuçları ve hasta prognozları ile bunlara etki eden faktörlerin araştırılmasıdır.

Yöntemler: Ocak 2012 - Ağustos 2015 tarihleri arasında PD uygulanan hastalara ait demografik, klinik ve laboratuvar veriler hastane otomasyon sistemi, hasta dosyaları ve aferez ünitesi kayıtlarından elde edildi.

Bulgular: Çalışma süresinde 40 hastaya toplam 168 defa PD uygulanmıştı. Hastaların ortanca yaşı 9,4 $(1,5-17,3)$ yıl, erkek/kız oranı 1,35 idi. Olguların \%47,5'i altta yatan bir hastalığa sahipti. En sık komorbid hastalık malignite idi. En sık PD endikasyonu sepsis ilişkili çoklu organ yetmezliği (19 hasta, \%47,5) olarak bulundu. Altta yatan kronik bir hastalığı olanlarda ölüm oranı olmayanlara göre daha yüksekti (sırası ile \%25 ve \%7,5). Hiçbir hastada aferez işlemi ile ilişkili yaşamı tehdit edici bir komplikasyon gelişmemişti.

Sonuç: Sonuçlarımı PD'nin çocuk hastalarda güvenle yapılabileceğini göstermektedir. Mortaliteyi etkileyen iki temel faktör PD endikasyonu ve altta yatan hastalık varlığı olarak bulunmuştur. Anahtar Kelimeler: Plazma değişimi, kritik hasta, çocuk

\section{Introduction}

Plasma exchange (PE) is the process in which plasma is exchanged with externally administered plasma or albumin for treatment purposes. ${ }^{1}$ It is one of the most common methods of therapeutic apheresis, and it can be life-saving in appropriate indications. In 2013, the American Society for Apheresis (ASFA) updated indications for therapeutic apheresis and classified them into four categories. ${ }^{1}$ In addition to the ASFA guidelines, the majority of the existing data on PE have been obtained from adult studies. Although studies are limited, ${ }^{2}$ experiences obtained from children indicate that PE is reliable in case of appropriate indications. ${ }^{3}$ Implementation of PE in pediatric intensive care units (PICUs) has increased lately. Furthermore, many diseases and conditions have been reported which are not included in the ASFA categories, but the efficacy of therapeutic apheresis has been presented as case reports or series. ${ }^{47}$ The aim of this study was to identify demographic and clinical characteristics of patients who were

Address for Correspondence/Yazışma Adresi: Halil Keskin MD, Atatürk University Faculty of Medicine, Division of Pediatric Intensive Care, Erzurum, Turkey Phone: +90 5334346734 E-mail: keskinpediatrize@gmail.com ORCID ID: orcid.org/0000-0003-4491-1327

Received/Geliş Tarihi: 27.11.2017 Accepted/Kabul Tarihi: 29.01.2018

- Copyright 2018 by Society of Pediatric Emergency and Intensive Care Medicine

Journal of Pediatric Emergency and Pediatric Intensive Care published by Galenos Yayınevi. 
subjected to PE in the PICU at a tertiary university hospital and to evaluate treatment indications, the efficacy and outcome of treatment, and patient prognosis.

\section{Materials and Methods}

The study was performed in the 200-bed children hospital of our university. A retrospective analysis was performed in patients who were subjected to PE between 01.01.2012 and 15.08.2015 in the PICU. Patient data were obtained from medical record of the patients, the hospital information system, and from the apheresis unit files. Approval for the study was obtained from the local ethics committee (2015/363). The study was conducted in accordance with the principles of the Declaration of Helsinki.

In all patients, indications for PE were determined by a committee including the staff of PICU, apheresis unit and departments related to the primary disease if present. The procedure was carried out using the Spectra Optia apheresis device. Acid-citrate-dextrose (ACD) solution was used in all procedures as an anticoagulant. Replacement with fresh frozen plasma (FFP) was performed for indications such as sepsis and hemophagocytic lymphohistiocytosis $(\mathrm{HLH})$, or in the presence of bleeding-causing comorbid diseases such as malignancies or aplastic anemia. Either FFP or albumin was chosen in the remaining patients. Dialysis catheter, placed in a central vein according to age and weight of patients, was used for the procedures.

The age, sex, PICU diagnosis, underlying disease if present, PE indication, number of procedures, complications associated with the procedure, and prognosis of the patients were recorded. Mean \pm SD was given for numerical data and number and percent were given for nominal data. Deaths occurred within seven days after the procedure were recorded as PE-associated mortality.

\section{Results}

Plasma exchange was performed in 40 patients for 168 times throughout the study. Clinical and demographic characteristics of the patients are demonstrated in Table 1.

The most common indications for PE were sepsis-related multiple organ failure (MOF) and HLH. Most of the patients had indications from ASFA III category ( $\mathrm{n}=22$ ) (Table 2).

Complications developed during a total of 18 sessions. The procedure was terminated in three of these. The most common complications were allergic reactions against blood products and catheter occlusion. Two of the complications which led to termination of the procedure were catheter occlusion, while the other one involved allergic reaction which occurred as shivering and respiratory distress. No life-threatening complication associated with the apheresis procedure was reported to develop in any of the patients (Table 3).

The mortality rate on the $28^{\text {th }}$ day of our study was $37.5 \%$. Procedure-related mortality rate was $32.5 \%(n=13)$, and 10 of these 13 patients had an underlying chronic disease.

Three patients had no comorbid disease, and only one session of PE was carried out in two of them. The mortality rate was found to be higher in patients with comorbidity, compared to

\begin{tabular}{ll|}
\hline Table 1. Clinical and demographic characteristics of the patients \\
\hline Age (year) [median (minimum-maximum)] & $9.4(1.5-17.3)$ \\
Male [number (\%)] & $23(57.5 \%)$ \\
Comorbid disease [number (\%)] & $19(47.5 \%)$ \\
Malignancy (ALL, AML, Wilms tm) & $14(74.0 \%)$ \\
CHARGE syndrome & $1(5.2 \%)$ \\
Chronic renal failure & $1(5.2 \%)$ \\
Chronic granulomatous disease & $1(5.2 \%)$ \\
Sarcoidosis & $1(5.2 \%)$ \\
Thalassemia major & $1(5.2 \%)$ \\
Diagnosis on PICU admission [number (\%)] & \\
Sepsis related multipple organ failure & $19(47.5 \%)$ \\
Hemophagocytic lymphohystiocytosis & $9(22.5 \%)$ \\
Encephalopathy & $4(10 \%)$ \\
Guillain-Barre syndrome & $2(5.0 \%)$ \\
Myasthenic crisis & $2(5.0 \%)$ \\
Thrombotic microangiopathy, HSCT associated & $2(5.0 \%)$ \\
Aplastic crisis & $1(2.5 \%)$ \\
Atypical hemolytic uremic syndrome & $1(2.5 \%)$ \\
ALL: Acute lymphoblastic leukemia, AML: Acute miyeloid leukemia, $\mathrm{HSCT}$ \\
Hematopoetic stem cell transplantation, PICU: Pediatric intensive care units \\
\hline
\end{tabular}

Table 2. Indications for PE and ASFA categories

\begin{tabular}{|c|c|c|c|}
\hline Cases & $\begin{array}{l}\text { Case number } \\
(n, \%)\end{array}$ & $\begin{array}{l}\text { Sessions } \\
(n, \%)\end{array}$ & ASFA \\
\hline Sepsis related MOF & $19(47.5 \%)$ & $66(39.3 \%)$ & III \\
\hline $\begin{array}{l}\text { Hemophagocytic } \\
\text { lymphohystiocytosis }\end{array}$ & $9(22.5 \%)$ & $44(26.1 \%)$ & * \\
\hline Guillain-Barre syndrome & $2(5 \%)$ & $11(6.5 \%)$ & 1 \\
\hline Myasthenic crisis & $2(5 \%)$ & $13(7.7 \%)$ & I \\
\hline $\begin{array}{l}\text { Toxic-methabolic } \\
\text { encephalopathy }\end{array}$ & $2(5 \%)$ & $7(4.2 \%)$ & * \\
\hline Refractory status epilepticus & $1(2.5 \%)$ & $2(1.2 \%)$ & * \\
\hline Autoimmune encephalitis & $1(2.5 \%)$ & $5(3.1 \%)$ & * \\
\hline $\begin{array}{l}\mathrm{HSCT} \text { associated thrombotic } \\
\text { microangiopathy }\end{array}$ & $2(5 \%)$ & $16(9.5 \%)$ & III \\
\hline $\begin{array}{l}\text { Atypical hemolytic uremic } \\
\text { syndrome }\end{array}$ & $1(2.5 \%)$ & $1(0.6 \%)$ & ॥ \\
\hline Aplastic anemia & $1(2.5 \%)$ & $3(1.8 \%)$ & III \\
\hline \multicolumn{4}{|c|}{$\begin{array}{l}\text { *Not included in ASFA } 2013 \text { categories, MOF: Multiple organ failure, HSCT: } \\
\text { Hematopoetic stem cell transplantation, ASFA: American Society for Apheresis }\end{array}$} \\
\hline
\end{tabular}


those without ( $25 \%$ and $7.5 \%$, respectively). The mortality rate in sepsis-related MOF, that was the most common indication for $\mathrm{PE}$, was distinctly higher in the presence of comorbidity, compared to absence of any underlying disease $(20 \%$ and $2 \%$, respectively). The survival rates in all patients and patients who underwent PE due to sepsis-related MOF, according to the presence of an underlying disease are shown in Table 4.

The demographic and clinical characteristics, PE indication, number of procedures and the ASFA categories in deceased patients are shown in Table 5.

Plasma exchange was performed in 13 patients who did not meet the ASFA category criteria; HLH $(n=9)$, toxic-metabolic

Table 3. Complications which developed during apheresis

\begin{tabular}{|llll|} 
& \multicolumn{2}{l}{ Complication } & Incomplete procedure \\
& Number $(\mathbf{n})$ & Ratio $(\%)$ & Number $(\mathbf{n})$ \\
Allergic reaction & 9 & 5.4 & 1 \\
Catheter occlusion & 6 & 3.6 & 2 \\
Hypocalcemia & 2 & 1.2 & 0 \\
Hypotension & 1 & 0.6 & 0 \\
Total & 18 & 10.8 & 3 \\
\hline
\end{tabular}

Table 4. Survival rates in patients with Sepsis related multiple organ failure and others according to the presence of underlying disease

\begin{tabular}{|lllll|}
\hline & \multicolumn{2}{l}{$\begin{array}{l}\text { With underlying disease } \\
\text { Sepsis } \\
\text { related MOF }\end{array}$} & All cases & \multicolumn{2}{l|}{$\begin{array}{l}\text { Without underlying disease } \\
\text { Sepsis related }\end{array}$} & All cases \\
MOF & & \\
Survived & $4(10 \%)$ & $9(22.5 \%)$ & $5(12.5 \%)$ & $18(45 \%)$ \\
Deceased & $8(20 \%)$ & $10(25 \%)$ & $2(5 \%)$ & $3(7.5 \%)$ \\
Total & $12(30 \%)$ & $19(47.5 \%)$ & $7(17.5 \%)$ & $21(52.5 \%)$ \\
MOF: Multiple organ failure & & & \\
\hline
\end{tabular}

encephalopathy $(n=2)$, refractory status epilepticus $(n=1)$, and autoimmune encephalitis $(n=1)$. None of these patients died.

\section{Discussion}

Although PE and plasmapheresis are often used interchangeably to refer the same condition, the two entities differ from each other. In plasmapheresis, blood is separated into two portions as cells and plasma. Then, some selected components in plasma are filtered and the remaining plasma is returned to the patient. On the other hand, PE entails the separation of blood into cells and plasma, after which patient plasma is exchanged with donor plasma or albumin while returning cells are returned into the patient. ${ }^{1}$ In all patients in our study, PE was performed by using donor plasma or albumin.

Although, implementation of PE is increasing in Turkey and the rest of the world, experiences in children are limited. The majority of information about this subject has been obtained from adult PE cases. ${ }^{8}$ Most cases of pediatric PE are performed in the PICU due to the need for a central vascular route, need for continuous monitoring, and due to some other factors such as underlying severe diseases.

In 2013, the ASFA updated indications for PE and grouped them into four categories. Accordingly, the ASFA-I category of diseases includes disorders where PE is accepted as primary therapy or as supplementary to the primary therapy; the ASFA-II category of diseases includes disorders where apheresis is used alone or in conjunction with other treatment as second-line therapy; the ASFA-III category of diseases includes disorders where the ideal role of therapeutic apheresis has not been established and

Table 5. Demographic and clinical characteristics and the American Society for Apheresis categories of deceased patients

\begin{tabular}{|c|c|c|c|c|c|}
\hline Patient no & Age (year) & Underlying disease & Indication for PE & Seance number & ASFA \\
\hline 1 & 15.9 & ALL & Sepsis related MOF & 5 & III \\
\hline 2 & 17.3 & ALL & Sepsis related MOF & 4 & III \\
\hline 3 & 3.4 & ALL & Sepsis related MOF & 2 & III \\
\hline 4 & 16.2 & ALL & Sepsis related MOF & 6 & III \\
\hline 5 & 15 & AML & Sepsis related MOF & 3 & III \\
\hline 6 & 8.3 & Wilms tumor & Sepsis related MOF & 1 & III \\
\hline 7 & 12.3 & CRF & Sepsis related MOF & 3 & III \\
\hline 8 & 3.6 & CHARGE syndrom & Sepsis related MOF & 5 & III \\
\hline 9 & 14.6 & - & Sepsis related MOF & 1 & III \\
\hline 10 & 16.3 & - & Sepsis related MOF & 5 & III \\
\hline 11 & 8.5 & ALL & Aplastic anemia & 3 & III \\
\hline 12 & 1.9 & AML & HSCT associated thrombotic microangiopathy & 6 & III \\
\hline 13 & 1.6 & - & Atypical HUS & 1 & $\|$ \\
\hline
\end{tabular}


where the procedure is case-specific; on the other hand, the ASFA-IV category of diseases includes suggested or known disorders where therapeutic apheresis has been shown to be ineffective or harmful. Therapeutic apheresis in this category is performed only under approved study protocols. ${ }^{1}$

Apart from the well-defined suggestions outlined in the ASFA 2013 guidelines, ${ }^{1}$ in many other life-threatening conditions which have been non-responsive to standard treatment, such as $\mathrm{HLH}$, refractory status epilepticus, and toxic-metabolic encephalopathy, it has been reported that PE might be beneficial. 4,6,9

As a matter of fact, during data collection for the present study, HLH was not included in the ASFA guideline, ${ }^{1}$ but recommended for the ASFA III category in the ASFA guidelines published in $2016 .{ }^{10}$ On the other hand, atypical hemolytic uremic syndrome (HUS) which was previously in the ASFA II category of the former guidelines has been removed from the ASFA category. ${ }^{10}$ In our study, PE was also performed in one patient due to atypical HUS. Only one session could be carried out in this patient before death.

In our study, PE was performed in 13 patients with four indications which were not included in the 2013 ASFA category. None of these 13 patients, of whom nine had HLH which is currently included in the ASFA III category, died. The results of our study may serve as prior information for prospective studies conducted on children and concerning other indications not currently included in the ASFA classification.

Many complications associated with the PE procedure have been described. ${ }^{11}$ In our study, the incidence of complications which necessitated discontinuation of the procedure was found to be very low. In none of the patients, a procedurerelated life-threatening complication such as sepsis, thrombosis, pneumothorax, hematoma, air embolism, arterial injury, hemolysis, coagulopathy, transfusion-related acute lung injury and anaphylactoid reaction developed.

There was an underlying disease in 10 of 13 patients who died, and in 12 of them the category of PE indication was in ASFA III. In two of three patients without any underlying disease who died, indication for PE was sepsis-related MOF. These were the most remarkable findings in our study.

The mortality rate was found to be high in patients who were subjected to PE due to sepsis-related MOF. The reason for this may be the fact that we performed PE as a salvage therapy in patients who were non-responsive to all previous treatments. Moreover, the mortality rate in patients with an underlying disease was found to be higher than in patients without, as it was noted in previous studies. ${ }^{12,13}$

\section{Study Limitations}

Relatively small sample size and its retrospective design are the limitations of our study.

\section{Conclusion}

In conclusion, our study results show that PE is a safe treatment method for critically ill children with the appropriate indication, and that the treatment is more effective in patients without comorbidity in addition to PE indication. In addition, we suggest that there are also other diseases which may be recommended in the further ASFA guidelines. However, further large-scale, prospective studies are required to shed light on this subject.

\section{Ethics}

Ethics Committee Approval: Ondokuz Mayıs University Clinical Research Ethics Committee (2015/363).

Informed Consent: Retrospective study.

Peer-review: Externally and internally peer-reviewed.

\section{Authorship Contributions}

Surgical and Medical Practices: M.Ş.P., N.Y., Ö.T.K., I.K., C.A., D.A., Concept: M.Ş.P., N.Y., Ö.T.K., I.K., C.A., D.A., Design: H.K., M.Ş.P., N.Y., Data Collection or Processing: H.K., M.Ş.P., N.Y., Analysis or Interpretation: H.K., M.Ş.P., N.Y., Literature Search: H.K., Writing: H.K.

Conflict of Interest: No conflict of interest was declared by the authors.

Financial Disclosure: The authors declared that this study received no financial support.

\section{References}

1. Schwartz J, Winters JL, Padmanabhan A, Balogun RA, Delaney $M$, et al. Guidelines on the use of therapeutic apheresis in clinical practice-evidence-based approach from the Writing Committee of the American Society for Apheresis: the sixth special issue. J Clin Apher. 2013;28:145-284

2. Kim YA, Sloan SR. Pediatric therapeutic apheresis: rationale and indications for plasmapheresis, cytapheresis, extracorporeal photopheresis, and LDL apheresis. Pediatr Clin North Am. 2013;60:1569-80.

3. Brunetta Gavranic B, Basic-Jukic N, Kes P. Therapeutic Plasma Exchange-Does Age Matter? A Single-Center Study. Artif Organs. 2016;40:786-92.

4. Abend NS, Dlugos DJ. Treatment of refractory status epilepticus: literature review and a proposed protocol. Pediatr Neurol. 2008;38:377-90

5. Khawaja AM, DeWolfe JL, Miller DW, Szaflarski JP. New-onset refractory status epilepticus (NORSE)-The potential role for immunotherapy. Epilepsy Behav. 2015;47:17-23.

6. Nguyen TC, Kiss JE, Goldman JR, Carcillo JA. The role of plasmapheresis in critical illness. Crit Care Clin. 2012;28:453-68. 
7. Wozniak K, Urbanowska E, Snarski E. [Plasmapheresis in haematology]. Wiad Lek. 2015;68:173-8.

8. Erbey F. Pediatride Terapötik aferez uygulamaları: Endikasyonlar ve Teknik Yaklaşım. Turkiye Klinikleri J Hematol-Special Topics. 2015;8:51-9.

9. Nakakura H, Ashida A, Matsumura H, Murata T, Nagatoya $\mathrm{K}$, et al A case report of successful treatment with plasma exchange for hemophagocytic syndrome associated with severe systemic juvenile idiopathic arthritis in an infant girl. Ther Apher Dial. 2009;13:71-6.

10. Schwartz J, Padmanabhan A, Aqui N, Balogun RA, Connelly-Smith $L$, et al. Guidelines on the Use of Therapeutic Apheresis in Clinical
Practice-Evidence-Based Approach from the Writing Committee of the American Society for Apheresis: The Seventh Special Issue. J Clin Apher. 2016;31:149-62.

11. Szczeklik W, Wawrzycka K, Wludarczyk A, Sega A, Nowak I, et al. Complications in patients treated with plasmapheresis in the intensive care unit. Anaesthesiol Intensive Ther. 2013;45:7-13.

12. Lehman KD, Thiessen K. Sepsis guidelines: Clinical practice implications. Nurse Pract. 2015;40:1-6.

13. Torres VB, Azevedo LC, Silva UV, Caruso P, Torelly AP, et al. SepsisAssociated Outcomes in Critically III Patients with Malignancies. Ann Am Thorac Soc. 2015:12:1185-92. 